\title{
Connections between microtubules and endoplasmic reticulum in mitotic spindle
}

\section{J. A. TARKOWSKA}

Laboratory of General Botany, Institute of Botany, Warsaw University, Warsaw

\begin{abstract}
Dividing endosperm cells of Haemanthus katherinae Bak. were treated with an 0.025 per cent aqueous solution of an oleander glycosides mixture which produces severe disturbances in the mitotic spindle and high hypertrophy of the endoplasmic reticulum (ER) in the whole cells. There appear between the kinetochore microtubules (MTs) numerous elongated and narrow ER cisterns, particularly well visible when the number of kinetochore MTs is reduced. Both these structures (MTs and ER) are frequently connected by cross-bridges. The presumable role of these connections is discused.
\end{abstract}

\section{INTRODUCTION}

The occurrence of transverse connections between the microtubules (MTs) of the mitotic spindle is well know and documented by numerous electron microscope photographs. The existence of these connections known as arms or cross-bridges has been demonstrated in various types of plant and animal cells (e.g. Ki e r m a y r, 1968; W il s on, 1969; Roth et al., 1970; Franke, 1971a,b; Burkholder et al., 1972; Fuge and M üller, 1972; Mooseker and Tilney, 1973; Bajer et al., 1975; Brinkle y and Cartwright, 1975; B urnsid e, 1975). Cross-bridges may also join MTs with other membraneous cell structures such as plasmalemma (C r o n shaw, 1967; Ki e rmayer, 1968; Rob a r d s, 1969), endoplasmic reticulum (W il s o n, 1970; Fr a n k e, 1971b;

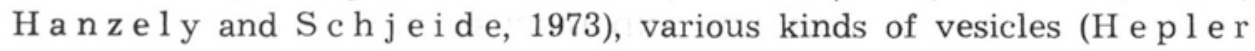
et al., 1970; $\mathrm{R}$ oth et al., 1970; Wils o n, 1970), the inner nuclear envelope (Wilson, 1969; Franke, 1971a) and even with chromatin (Fuge and Müller, 1972).

Particularly noteworthy are so far scarce reports on the existence of such connections between the microtubules and endoplasmic reticulum. 
The presence of endoplasmic reticulum (ER) in the mitotic apparatus of various types of higher plant cells has been demonstrated by numerous authors (e.g. Porter and $\mathrm{Mach}$ ado, 1960; Pickett-Heaps and $\mathrm{N}$ orthcote, 1966; Wils on, 1970 ; $\mathrm{Hanzely}$ and $\mathrm{Schjeide}$, 1973; B a j e r et al., 1975). It is supposed that the ER membranes accumulating as early as prophase on the future cell pole serve as "base" for the forming mitotic spindle. They seem to correspond to the centrosome in animals. The ER cisterns between the MTs of the spindle appear to have a strengthening function. The question arises whether this is their only role.

Pickett-Heaps and Northcote (1966) and also Bajer et al. (1975) call attention to the mutual close neighbourhood of both these structures, and even the possibility of ER lamelle passing gradually into MTs and vice versa. None of above quoted authors, however, was able to demonstrate the existence of any connections between these structures. The occurrence of cross-bridges between MTs and ER has only been detected and described by $\mathrm{Franke}(1971 \mathrm{~b})$ in Tetrachymena pyriformis, not in the spindle, however, but in the peripheral part of the cytoplasm. A short communication of $\mathrm{Hanzley}$ and $\mathrm{Schjeide}$ (1973) also reports the presence of various types undefined connections between smooth ER and MTs, both at the pole and within the mitotic spindle of dividing meristematic cells of Allium sativum.

\section{MATERIAL AND METHODS}

As object for the studies served endosperm cells of Haemanthus katherinae Bak. pressed out onto medium and treated with an aqueous 0.025 per cent solution of a glycoside mixture of Nerium oleander (Oleander Gesamtglycoside, Laborchemikalien, Carl Roth OHG, Karlsruhe-West). The preparations for the electron microscope were made according to the technique elaborated by $\mathrm{M}$ ol è- $\mathrm{B} \mathrm{a} \mathrm{j} \mathrm{e} \mathrm{r} \mathrm{and} \mathrm{B} \mathrm{a} \mathrm{j} \mathrm{e} \mathrm{r} \mathrm{(1968).}$ Sections of mean thickness $100 \mathrm{~nm}$ were prepared with a LKB ultramicrotome, observations were noted and photographs were taken with a Siemens Elmiscop IA operated at $80 \mathrm{KV}$.

\section{RESULTS AND DISCUSSION}

Oleander glycosides produce significant disturbances in the cell morphology and in cell division, both karyokinesis and cytokinesis (T a r ow ska, 1976). These disorders consist in abnormal movements of the chromosome caused by direct inhibition of mitotic spindle formation and disorganization (destruction of MTs) of the already existing 

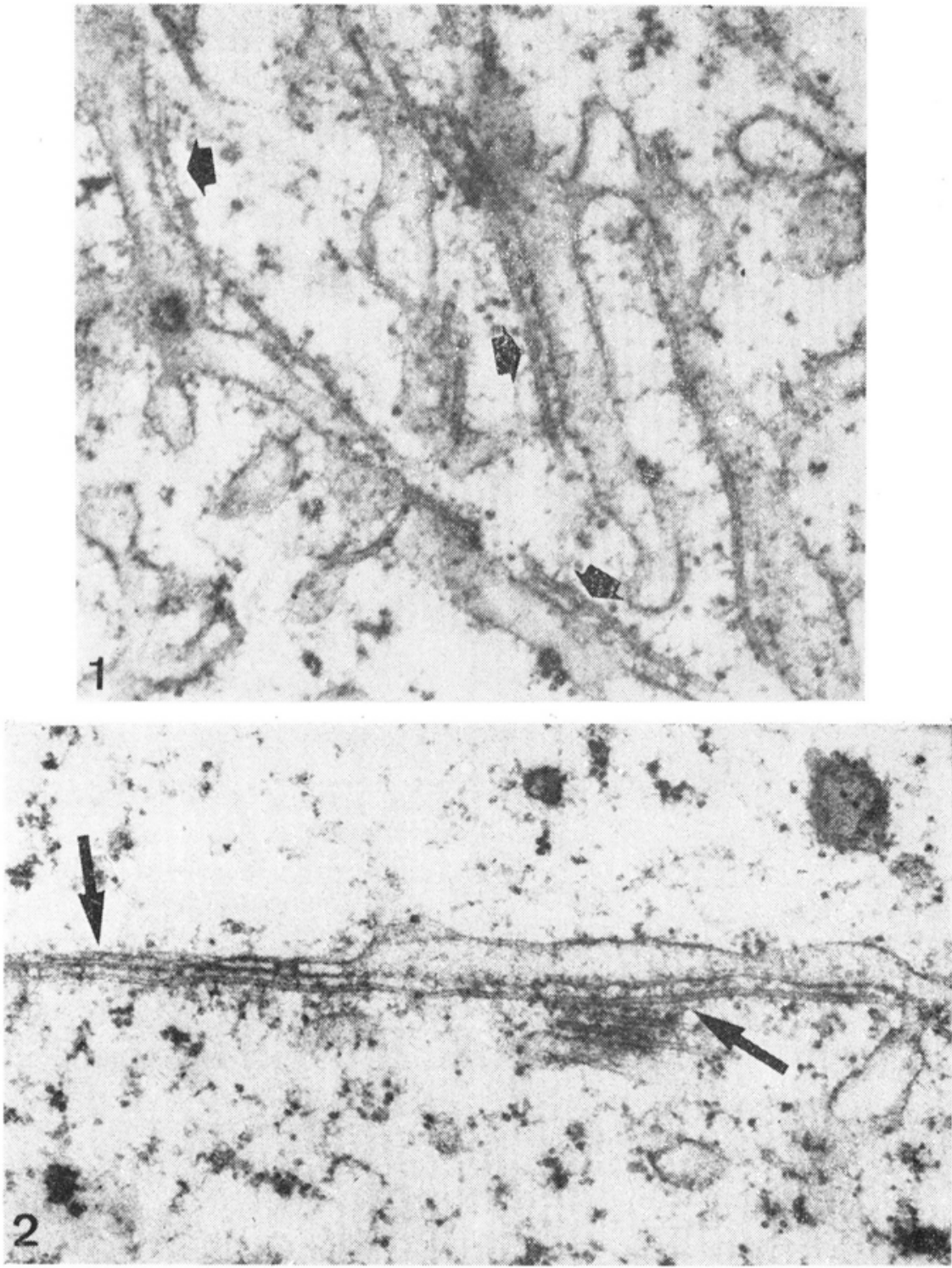

Fig. 1 - The part of kinetochore bundle in prometaphase. Connections between MTs and ER cisterns are visible (arrows). Magn. ca $42000 \times$

Fig. 2 - The middle part of kinetochore bundle in metaphase. Connections between MTs and long cistern of ER (arrows) Magn. ca $36000 \times$ 
spindle. The action of glycosides also produces a strong hypertrophy of the endoplasmic reticulum in the whole cell ( $\mathrm{T}$ a r k ow s a, in preparation). Numerous, usually long and narrow ER cisterns appear also among the microtubules in the kinetochore bundle where both the structures are usually arranged parallelly and transverse connections may by seen between them close to the kinetochores and also at longer distances from them. These connections correspond in their appearance, size and situation to the cross-bridges appearing between neighbouring microtubules in normal mitosis, and also after treatment with oleander glycosides. It would seem, therefore, that the terms "arsm" or "cross-bridges" may be applied to them. The occurrence of cross-bridges between the MTs and ER has been observed by the author in prometaphase (Fig. 1) and metaphase (Fig. 2). Single superposed cross-bridges are distributed at more or less regular distances. They join the MTs and ER membranes usually in the inner part of the kinetochore bundle. These connections become most distinctly visible when the number of kinetochore MTs is greatly reduced (after ca. $1 \mathrm{~h}$ and $30 \mathrm{~min}$ of glysocide treatment). Both these structures are then almost ideally parallel, and the ER cisterns are relatively narrow.

The occurrence and role of the transverse connections between the MTs is differently interpreted by various authors. Most of them, however, belive that the cross-bridges play a stabilizing role, supporting the spindle. It is also suggested recently more and more frequently that the cross-bridges joining the neighbouring MTs of the spindle play an active role during the anaphase movements of chromosomes. Numerous biochemical investigations performed in recent years indicate the presence (also in higher plants) of actin in these cross-bridges (e.g. F o r e r and $\mathrm{J} \mathrm{a} \mathrm{ckson,1975;} \mathrm{M} \mathrm{c} \mathrm{In} \mathrm{t} \mathrm{o} \mathrm{s} \mathrm{h} \mathrm{et} \mathrm{al.,} \mathrm{1975)} \mathrm{or} \mathrm{of} \mathrm{myosin} \mathrm{(H} \mathrm{e} \mathrm{ple} \mathrm{r}$ and $\mathrm{Palevitz}, 1974$ ) or else dynein (Mooseker and Tilney, 1973; B u rnside, 1975). All these compounds are present in the muscle tissues of animals and their presence is associated with movement. An additional argument supporting the active role of the cross-bridges is the presence in mitotic apparatus of actin fibers detected for the first time in a representative of higher plants (Haemanthus katherinae) by F orer and J a ckson (1975). Thus the cross-bridges between the MTs would be connected with the indispensable energy for chromosome translocation. After treatment with agents destroying the cross-bridges in the remaining MTs, become more distinctly visible than in normal mitosis. This was observed by B rink ley and C a r tw righ t (1975) in cells of mammals under the effect of low temperature and by present author in the endosperm cells after treatment with oleander glycosides. It cannot, however, be concluded that the use of these agents increases the number of connections, but they are better visible when the number of MTs is reduced. 
On the basis of the present studies it is suggested that the numerous elongated ER cisterns appearing between the kinetochore MTs are structures which have to take over the function of the destroyed MTs. The cross-bridges (as sources of energy) present between the remaining MTs and ER cisterns would make possible at least slight movements of the chromosomes. Similar suppositions are advanced by B a jer et al. (1975) who suggest that the endoplasmic reticulum accompanying the kinetochore MTs may, beside supporting the kinetochore bundle, be utilized as a support during the movement of the chromosome in anaphase. The mentioned authors, however, do not refer this function of the endoplasmic reticulum to the presence of transvere connections and did not demonstrate their presence.

Acknowledgment:

It is my pleasure to thank prof. dr J. Szulet a for his helpful comments.

\section{REFERENCES}

B a j e r A. S., Molè - B a j e r J. and La mbert A. M., 1975. Lateral interaction of microtubules and chromosome movements, in "Microtubules and Microtubule Inhíbitors", ed. Borgers and Brabander, North-Holland Publ. Comp., Amsterdam 393-423.

Brinkley B. R., Cartwright J., Jr, 1975. Cold-labile and cold-stable microtubules in the mitotic spindle of mammalian cells, Ann. N.Y. Acad. Sci, 253: 428-439.

B urkholder G. D., Okada T. A. and Coming s D. E., 1972. Whole mount "eléctron microscopy of métaphase I. Chromosomes and microtubules from mouse oocytes, Exp. Cell Res. 75: 497-511.

B urnside B.; 1975. The: form and arrangement of microtubules: an historical, primarily morphological, review, Ann. N.Y. Acad. Sci. 253: 14-24.

Cronshaw J., 1967. Tracheid differentiation in tabaco pith cultures, Planta 72: 78-90.

F orer A. and Jacks on Wm. T., 1975. Actin in the higher plant Haemanthus katherinae Baker, Cytobiol. 12: 199-214.

Franke W. W., 1971a. Cross-bridges between intramacronuclear microtubules and inner nuclear membrane. Z . Naturfor. 26b: 626-627.

F r a n ke W, W., 1971b. Cytoplasmic microtubules linked to endoplasmic reticulum with cross-bridges, Exp. Cell Res. 66: 486-489.

Fug e H. and M üller W., 1972. Mikrotubuli-Kontakt an Anaphase-chromosomen in der I meiotischen Teilung, Exp. Cell Res. 71: 241-245.

$\mathrm{Hanzely}$ L. and Schjeide O. A., 1973. Structural analysis of the anastral mitotic spindle in plant cells, J. Cell Biol. 58: 132a.

Hie ple r P. K., M c In tos h. R. and C le land S., 1970. Intramicrotubule bridges in mitotic spindle apparatus, J. Cell Biol. 45: 438-444.

Hepler P. K, and Palevitz B. A., 1974. Microtubules and microfilaments, Ann. Rev. Plant Physiol. 25: 309-362. 
Kierma y e O., 1968. The distribution of microtubules in differentiating cells of Micrasterias denticulata Bréb., Planta 83: 223-236.

McIntosh J. R., Cande Z., Snyder J. and Vanderslice K., 1975. Studies on the mechanism of mitosis, Ann. N.Y. Acad. Sci. 253: 407-427.

M o l è-B a jer J. and B a jer A., 1968. Studies of selected endosperm cells with the light and electron microscopy the technique, La Cellule 67: 257-265.

Mooseker M. S. and Tilney L. G., 1973. Isolation and reactivation of the axostyle. Evidence for a dynein-like ATPase in the axostyle J. Cell Biol. J6: $13-26$.

Pickett-Heaps J. D. and Northcote D. H., 1966. Organisation of microtubules and endoplasmic reticulum during mitosis and cytokinesis in wheat meristems, J. Cell Sci. 1: 109-120.

P orter K. R. and M a ch a d o R. D., 1960. Studies on the endoplasmic reticulum. IV. Its form and distribution during mitosis in cells of onion root tip. J. Biophys. Biochem. Cytol. 7: 167-180.

Robards. A. W., 1969. Particles associated with developing plant cell walls, Planta 88: $376-379$.

Roth L, E, Pihlaja. D, J. and Shigenaka, J, 1970. Microtubules in the heliozoan axopodium I. The gradion hypothesis of allosterism in structural proteins, J. Ultrastr. Res. 30: 7-37.

$\mathrm{T}$ a r k ow ska J. A., 1976. Investigations in vitro on the behaviour of chromosomes and the mitotic apparatus in endosperm cells of Haemanthus katherinae Baker treated with oleander glycosides, Acta Soc. Bot. Pol. 45: 271-283.

Wils on H. J., 1969. Arms and bridges on microtubules in the mitotic apparatus, J. Cell Biol. 40: 854-859.

Wils on H. J., 1970. Endoplasmic reticulum and microtubule formation in dividing cells of higher plants- a postulate, Planta 94: 184-190.

Autors's address:

Dr Jadwiga A. Tarkowska

Laboratory of General Botany

University of Warsaw,

Krakowskie Przedmieście 26/28

00-927 Warsaw, Poland

\section{Połącenia między mikrotubulami i endoplazmatycznym reticulum wrzeciona mitotycznego}

\section{Streszczenie}

Przedmiotem badań były wyciśnięte na pożywkę komórki bielma Haemanthus katherinae Bak. poddane działaniu $0.025 \%$ wodnego roztworu mieszaniny glikozydów oleandra. Dzielące się komórki obserwowano początkowo in vitro w mikroskopie świetlnym, a następnie te same komórki utrwalano i przygotowywano do badań w mikroskopie elektronowym wg techniki opracowanej przez M olè-B a jer i Bajer (1968). Skrawki grubości ok. $100 \mathrm{~nm}$ wykonano ultramikrotomem LKB, barwiono octanem uranylu i cytrynianem sodu. Obserwacje przeprowadzono i zdjęcia wykonano w mikroskopie elektronowym Siemens IA, przy $80 \mathrm{KV}$.

Glikozydy oleandra wywołują zaburzenia w budowie wrzeciona mitotycznego oraz silną hypertrofię endoplazmatycznego retikulum (ER) w całej komórce. Wśród 
mikrotubul (MTs) kinetochorowych pojawiają się liczne, zwykle długie i wąskie cysterny ER, szczególnie dobrze widoczne po znacznej redukcji liczby MTs przy kinetochorach. Obie te struktury (MTs i ER) połączone są często poprzecznymi połączeniami - mostkami. Połączenia te wyglądem, wielkością i położeniem odpowiadają mostkom występującym między mikrotubulami w normalnej mitozie i widoczne są także po działaniu glikozydami oleandra. Występowanie mostków między MTs i ER stwierdzono w prometafazie (Fig. 1) i w metafazie (Fig. 2).

Przypuszcza się (np. B ajer i wsp., 1975), że mostki te pełnią rolę stabilizującą, usztywniającą wrzeciono. Badania biochemiczne wielu autorów wskazują na obecność w nich aktyny (m.in. Forer i J a ckson, 1975; M c I t os h i wsp., 1975), miozyny (Hepler i Palevitz, 1975), czy dyneiny (Mooseker i Tilney, 1973; Burnside, 1975), tj. związków występujących w mięśniach zwierząt, gdzie obecność ich związana jest z ruchem.

Autorka tej pracy przypuszcza, że występujące w wiązce kinetochorowej i zwykle równoległe do MTs, wydłużone cysterny ER są strukturami funkcjonalnie zastępującymi zniszczone przez glikozydy MTs. Natomiast mostki, łączące pozostałe mikrotubule wiązki kinetochorowej z cysternami ER, można uważać za źródło energii umożliwiającej niewielkie przesunięcia (ruchy) chromosomów. 